\title{
Musik sebagai Media di Ladang Misi
}

\author{
Rini Sumanti Sapalakkai ${ }^{1}$, Fransiskus Irwan Widjaja² ${ }^{2}$ Fredik Melkias Boiliu ${ }^{3}$ \\ ${ }^{1,2,3}$ Sekolah Tinggi Teologi REAL, Batam \\ Correspondence: rinigenovita@gmail.com
}

\begin{abstract}
Music functions as a communication tool to reach the soul by proclaiming the truth of God's word. Music has a very helpful role in evangelism through songs that are created and sung as a testimony to true stories in the lives of believers who declare that Jesus is Lord and Savior. This study aims to discuss music as the spearhead of the mission field. The method used in this research is a literature study approach, carried out by collecting data relevant to the topic or problem in this research. The results of this study will describe music as a medium of worship, music as a medium for preaching God's word, and music as the spearhead of harvesting the mission field.
\end{abstract}

Keywords: Christian music; mission field; media of mission; music ministry

\begin{abstract}
Abstrak: Musik berfungsi sebagai alat komunikasi untuk menjangkau jiwa dengan memberitakan kebenaran firman Tuhan. Musik memiliki peran yang sangat membantu dalam pekabaran injil melalui lagu yang diciptakan, dinyanyikan sebagai sebuah kesaksian kisah nyata dalam kehidupan orang percaya yang menyatakan bahwa Yesus adalah Tuhan dan Juruselamat. Penelitian ini bertujuan untuk membahas musik sebagai instrumen yang penting di ladang misi. Metode yang digunakan dalam penelitian ini adalah pendekatan studi kepustakaan, dilakukan dengan mengumpulkan data yang relevan dengan topik atau permasalahan dalam penelitian ini. Hasil penelitian ini akan mendeskripsikan mengenai musik sebagai media dalam ibadah, musik sebgai media pemberitaan firman Tuhan, dan musik sebagai ujung tombak penuaian ladang misi.
\end{abstract}

Kata Kunci: ladang misi; media misi; musik Kristiani; pelayanan musik

\section{Pendahuluan}

Media musik dan ladang misi pada hakikatnya adalah dua hal yang tidak dapat dipisahkan, karena sama-sama saling mendukung satu dengan yang lain. Pada zaman sekarang ini media musik dapat di jumpai dimana-mana terkhusus dalam dunia pelayanan. Dan dapat disaksikan di setiap gereja pujian penyembahan selalu diiringi oleh media musik dengan lagu rohani yang baru serta begitu banyak cara yang kreatif digunakan dalam memuji dan menyembah Tuhan. Secara Umum gereja telah menerima media musik menjadi bagian penting di ladang misi. Meskipun demikian, media musik yang diterima dalam ladang misi sangat ditentukan oleh denominasi dan juga oleh keterbukaan gereja terhadap perkembangan musik dalam kebudayaan manusia. Hal tersebut memuncul perdebatan baru mengenai betuk musik yang dapat atau tidak dapat diterima oleh gereja. Pertanyaan mengenai jenis media musik apakah yang dapat diterima oleh didalam ladang misi. Telah menjadi pertanyaan yang digemakan sepanjang pergumulan gereja dalam menghadapi ekselerasi perkembangan musik.

Beberapa gereja menganggap bahwa tidak semua jenis musik dapat digunakan dalam liturgi. Menurut Putra Hendra Sitopul bahwa musik media musik digunakan dalam keagamaan 
harus meningkatkan meditasi dan pemikiran rohani. Alunannya harus indah dan menarik, tetapi tidak sentimental. Melodi dan harmonisnya harus kuat, efektif dan memuaskan tetepi tidak manis atau lemah. ${ }^{1}$ Pernyataan ini memberikan keterangan mengenai jenis musik yang secara umum dapat diterima dalam liturgi yang dilaksanakan oleh gereja. Oleh karena itu musik dengan kehidupan manusia sangat erat terutama secara emosional. Jadi musik merupakan suatu ilmu, sehingga dapat dijabarkan atau dibicarakan secara ilmiah. Namun musik juga merupakan suatu seni, sehingga dapat dipakai sebagai ungkapan isi hati seorang seniman untuk mewujudkan keindahan ataupun idealisme yang dibayangkan. Musik sebagai ilmu dan seni bersifat aktif dan dinamis, selalu bergerak maju untuk mencari hal-hal baru. Musik diciptakan oleh manusia, namun manusia juga dipengaruhi olehnya. Sejarah kehidupan manusia dapat dikenal melalui sejarah musiknya. Demikian halnya juga gereja bertanggung jawab penuh dalam melaksanakan misi Allah sebagai pemegang kunci kerajaan sorga yaitu tempat yang Allah inginkan semua orang masuk di dalamnya, maka gereja mempunyai tanggung jawab besar dalam melaksanakan tugas panggilan tersebut. ${ }^{2}$

\section{METODE}

Metode yang digunakan dalam penelitian ini adalah studi kepustakaan (library research). Studi kepustakaan merupakan segala usaha yang dilakukan oleh peneliti untuk menghimpun data yang relevan dengan topik atau masalah yang sedang diteliti. ${ }^{3}$ Penelitian ini bertujuan untuk mengkaji teks, buku, dan jurnal ilmiah musik gereja yang pembahasannya sesuai dengan konsep dan permasalahan dalam kajian ini. Pengumpulan data dalam penelitian ini, diambil dari berbagai jurnal ilmiah nasional dan buku-buku musik gereja. Pengolahan data dalam penelitian ini dengan cara mencari literatur di jurnal-jurnal ilmiah, buku-buku teks, membaca, membandingkan, diolah atau dideskripsikan dan menghasilkan kesimpulan. Data yang digunakan dalam penelitian ini adalah data sekunder yang diperoleh dari buku-buku, jurnal ilmiah, serta artikel ilmiah lainnya yang berkaitan dengan konsep dalam kajian ini.

\section{Hasil dan Pembahasan}

\section{Musik sebagai Media dalam Ibadah}

Dapat dipahami bahwa musik dan gereja merupakan dua hal yang tidak dapat dipisahkan sehingga dalam agama Kristen di sebut sebagai agama yang bernyanyi. Menurut Picanussa gereja tanpa musik bagaikan burung yang tidak memiliki kegua sayapnya. ${ }^{4}$ Bert Penny Pahan. ${ }^{5}$ Mengemukakan dapat mendefenisikan musik gsebagai ilmu, musik gereja adalah pengetahuan tentang hal menghubungkan nada-nada, dalam berbagai macam irama, medoli/lagu dan harmoni untuk mengahasilkan komposisi yang mampu mengungkapkan pikiran dan emosi manusia dalam hubungannya dengan Tuhan yang diyakini. Musik sebagai hasil karya seni, nada yang berbentuk vokal atau bunyi instrumental yang disusun sedemikian rupa sehingga menghasilkan komposisi suara/bunyi yang mengandung irama, melodi/lagu dan har-

\footnotetext{
${ }^{1}$ Putra Hendra Sitopul, "Musik Dalam Dinamika Pujian Penyembahan," PNEUMATIKOS 10, no. 2 (2020): 176-99.

${ }^{2}$ Fransiskus Irwan Widjaja, Misiologi Antara Teori, Fakta Dan Pengalaman (Yogyakarta: Andi Offset, 2018).

${ }^{3}$ Hermawan Iwan, Metodologi Penelitian Pendidikan Kuantitatif, Kualitatif, Dan Mixed Methode (Kuningan: Hidayatul Quran Kuningan, 2019).

4 Picanussa, "Musik Sebagai Media Berbagi Iman," Kenosis 3, no. 1 (2017): 73-86.

${ }^{5}$ Bert Penny Pahan, "Perkembangan Musik Gereja Dan Intepretasi Pemusik Gereja Terhadap Nyanyian Jemaat Di Gereja Sinta Kuala Kapuas Danum Pambelum Jurnal Teologi Dan Musik Gereja," Danum Pambelum 1, no. 1 (2021): 119-31.
} 
moni yang merupakan satu kesatuan yang utuh, berkesinambungan, mengespresikan pikiran dan emosi komposer.

Musik dapat mempengaruhi pikiran dan emosi orang yang mendengarkan dan mengakibatkan perubahan sikap dan perilaku pada orang tersebut yang memuliakan Tuhan serta sebagai respon karya penyelamatan Tuhan di dalam Kristus untuk orang berdosa. Febriyani Sitepu mendefinisikan musik gereja sebagai musik yang berkembang di Gereja pada umat Kristen untuk kepentingan Ibadah. ${ }^{6}$ Alrik Lapian, dkk., mengatakan musik gereja gereja merupakan unsur penting dalam peribadatan umat Kristen, terlebih pada ibadah anak-anak. ${ }^{7}$ dengan demikian, dapat dipahami bahwa musik gereja merupakan suatu instrument yang menghasilkan suatu nada yang indah dan merdu serta memiliki peran penting dalam sebua acara, ibadah yang berkaitan dengan acara-acara yang menggunakan musik (pernikahan, uapan syukur). Alat musik memiliki jenis yang berbeda-beda seperti piano, keybord, gitar, bass, drum, dan sebagainya.

Dalam hal ini, musik sangat penting dalam ibadah gereja karena sebagian besar porsi ibadah gereja memiliki unsur musik baik vocal maupun instrumental. Menurut Mewena musik adalah cetusan ekspresi isi hati yang di ungkapkan dalam bentuk bunyi yang bernada dan berirama khususnya dalam bentuk lagu dan nyanyian. ${ }^{8}$ Begitu pentingnya musik di gereja sehingga Martin Luther mengatakan gereja yang baik adalah gereja yang bernyanyi. ${ }^{9}$ Artinya bahwa makna musik dalam ibadah gereja adalah liturgy gereja yang merupakan ungkapan simbolis perayaan iman jemaat. Hal ini menunjukkan bahwa hubungan musik dengan liturgy hsrus bersifat harmonis yaitu adanya keseimbangan yang pas antara musik dan penyataan iman menjadi satu. Senada dengan ini, Winnardo Saragih mengatakan musik dapat membantu ibadah karena lebih bersifat ekspresif dibanding dengan hanya sekedar berbicara. Oleh sebab itu, unsur musik dalam ibadah di gereja harus memiliki keterkaitan dengan pengembangan kehidupan spiritual, sumber daya, organisasi gereja, mentalitas, keahlian, integritas keteladanan sesuai dengan standar iman Kristen. ${ }^{10}$

\section{Musik sebagai Ujung Tombak Penuain di Ladang Misi}

Media musik merupakan ujung tombak penuain ladang misi, dalam hal ini musik berfungsi sebagai alat komunikasi untuk menjangkau orang dengan berita tentang Allah. Artinya misi dari musik rohani adalah sebagai model bahasa yang digunakan untuk mengkomunikasi firman Tuhan. Oleh sebab itu, musik yang digunakan dalam penginjilan harus tersampaikan lewat pujian yang diterima pendengar dengan jelas sehingga mudah memahami kebenaran firman Tuhan. Musik memiliki peran yang sangat membantu dalam pekabaran injil misalnya melalui banyak musik dan lagu yang diciptakan, dinyanyikan sebagai sebuah

\footnotetext{
${ }^{6}$ Febriyani Sitepu, “Penggunaan Software Guitar Pro Untuk Meningkatkan Kemampuan Bermain Gitar Melodi Di Gereja Tesalonika Bandung" (Universitas Pendidikan Indonesia, 2016), http://repository.upi.edu/33254/.

${ }^{7}$ Stefany Mersiany Pandaleke Alrik Lapian, Meylsant Herbet Maragani, "Pendidikan Melalui Aktivitas Musikal Dalam Ibadah Online Anak Sekolah Minggu GMIM Exodus Paniki Dua," Clef 2, no. 1 (2021): 19-31, http://ejournal-iakn-manado.ac.id/index.php/clef/article/view/506.

${ }^{8}$ Mewena, Gereja Yang Bernyanyi (Yogyakarta: Andi Offset, 2004).

${ }^{9}$ Mocchamad Usman Wafa Frans Jimmy Simanjuntak, Wadiyo, "Penggunaan Musik Dalam Ibadah Kontemporer Di Gereja Huria Kristen Batak Protestan (HKBP) Jemaat Semarang Barat," Seni Musik 6, no. 2 (2017): 35-44.

${ }^{10}$ Winnardo Saragih, Misi Musik: Menyembah Atau Menghujat Allah (Yogyakarta: Andi Offset, 2008).
} 
kesaksian kisah nyata dalam kehidupan orang percaya yang menyatakan bahwa Yesus adalah Tuhan dan Juruselamat yang hidup, berkuasa dan mengasihi umat manusia yang berdosa. ${ }^{11}$

Senada dengan ini, Hari Sasongkoh mengemukakan beberapa hal penting mengenai musi gereja yaitu: (a) bersifat rohaniah, (c) dimainkan di hadapan Jemaat Kristus, (d) musik gereja harus dapat membangun suasana ibadah/suasa liturgis, (e) musik harus mampu membawa jemaat masuk ke dalam hadirat Allah. Dengan demikian, dapat dipahami dalam musik syair harus di angkat langsung dari alkitab atau ayat-ayat firman Tuhan sebab musik berasal dari Allah, dipergunakan untuk kemulian Allah sesuai dengan porsi yang benar sebagai wujud mengembalikan kepada Allah. Picanusa mengemukakan bahwa melalui musik para misionari dari berbagai zaman telah menggunakan untuk menhajar dan menyebarkan iman Kristen, musik sebagai media untuk menyampaikan firman Tuhan kepada anak-anak dan musik sebagai media untuk menyampaikan firman Tuhan kepada orang yang tidak mengenal Tuhan Yesus. ${ }^{12}$

\section{KESIMPULAN}

Berdasarkan kajian ini, penulis melihat bahwa media musik sangat di perlukan dalam dunia pelayanan terutama di ladang misi. Ladang misi akan sangat terbantu dengan kehadiran media musik artinya ibadah tidak menjadi kaku dan monoton melainkan menumbuhkan semangat para jemaat dalam mengikuti ibadah yang diselenggarakan. Sedangkan misi merupakan suatu tugas yang gereja tanggapi sebagai amanat agung atau perintah langsung dari Tuhan Yesus dalam rangka peranannya di dunia ini. Misi bukanlah pilihan yang dapat di pertimbangkan tetapi misi adalah suatu perintah yang harus dilaksanakan. Tujuan dari misi yaitu untuk memulihkan hubungan manusia dengan Allah, membawa orang mengenal satusatunya Allah yang benar dan memuliahkan Allah. Misi juga merupakan rangcangan damai sejatehra dari Allah untuk menyelamatkan dan menyatakan kerajaanNya di dunia.

\section{REFERENSI}

Alrik Lapian, Meylsant Herbet Maragani, Stefany Mersiany Pandaleke. "Pendidikan Melalui Aktivitas Musikal Dalam Ibadah Online Anak Sekolah Minggu GMIM Exodus Paniki Dua." Clef 2, no. 1 (2021): 19-31. http://ejournal-iaknmanado.ac.id/index.php/clef/article/view/506.

Ance Juliet Pangabean. "Suatu Pemahaman Pernan Dan Pengaruh Musik Terhadap Kerohanian Dalam Ibdah Gereja Kharismatik Di Medan." Visi 20, no. 2 (2012): 968-85.

Bert Penny Pahan. "Perkembangan Musik Gereja Dan Intepretasi Pemusik Gereja Terhadap Nyanyian Jemaat Di Gereja Sinta Kuala Kapuas Danum Pambelum Jurnal Teologi Dan Musik Gereja." Danum Pambelum 1, no. 1 (2021): 119-31.

Branckly Eiberth Piccanussa. "Musik Sebagai Media Berbagi Iman." Kenosis 3, no. 1 (2017): 73-86.

Febriyani Sitepu. "Penggunaan Software Guitar Pro Untuk Meningkatkan Kemampuan Bermain Gitar Melodi Di Gereja Tesalonika Bandung." Universitas Pendidikan Indonesia, 2016. http://repository.upi.edu/33254/.

Frans Jimmy Simanjuntak, Wadiyo, Mocchamad Usman Wafa. “Penggunaan Musik Dalam Ibadah Kontemporer Di Gereja Huria Kristen Batak Protestan (HKBP) Jemaat Semarang Barat." Seni Musik 6, no. 2 (2017): 35-44.

Fransiskus Irwan Widjaja. Misiologi Antara Teori, Fakta Dan Pengalaman. Yogyakarta: Andi Offset, 2018.

\footnotetext{
11 Ance Juliet Pangabean, "Suatu Pemahaman Pernan Dan Pengaruh Musik Terhadap Kerohanian Dalam Ibdah Gereja Kharismatik Di Medan," Visi 20, no. 2 (2012): 968-85.

${ }^{12}$ Branckly Eiberth Piccanussa, "Musik Sebagai Media Berbagi Iman," Kenosis 3, no. 1 (2017): 73-86.
} 
Hermawan Iwan. Metodologi Penelitian Pendidikan Kuantitatif, Kualitatif, Dan Mixed Methode. Kuningan: Hidayatul Quran Kuningan, 2019.

Mewena. Gereja Yang Bernyanyi. Yogyakarta: Andi Offset, 2004.

Picanussa. "Musik Sebagai Media Berbagi Iman." Kenosis 3, no. 1 (2017): 73-86.

Putra Hendra Sitopul. "Musik Dalam Dinamika Pujian Penyembahan." PNEUMATIKOS 10, no. 2 (2020): 176-99.

Winnardo Saragih. Misi Musik: Menyembah Atau Menghujat Allah. Yogyakarta: Andi Offset, 2008. 